\title{
Understanding State Incorporation of the Workers' Movement in Early Post-War Lebanon and its Backlash on Civil Society
}

Lea Bou Khater

\begin{abstract}
This paper analyses the part played by the organised workers' movement in the political and economic struggle for change in Lebanon during the first decade of the post-civil war period. It seeks to explain the trajectory of the workers' movement, represented by the General Confederation of Workers in Lebanon (GCWL), and their successes and failures during the period in question. It investigates the structure and legal framework within which trade unions and leagues were created, as well as their past political affiliations or alliances. In doing so, the research examined labour provisions, the structural framework of the organised workers' movement, GCWL documents as well as newspaper archives, which reveal different facets of state-labour relations in Lebanon. As such, the paper begins by briefly charting the main issues affecting state-labour relations, then goes on to advance that the workers' movement was significantly weakened by state and the ruling elite intervention, repression, and eventually, state incorporation.
\end{abstract}

Keywords: Trade unions, labour movement, state incorporation, mobilisation, wage-earners, GCWL

This paper was first published in the 3rd issue of the Civil Society Review: https://civilsocietycentre.org/resource/civil-society-review-issue-3-unraveling-\%E2\%80\%9Ccivilsociety\%E2\%80\%9D-policydependency-networks-and

Published on Lebanon Support's Civil Society Knowledge Centre: https://civilsocietycentre.org/paper/understanding-state-incorporation-workers-movement-early-post-war-lebanonand-its-backlash 


\section{Introduction}

Over the last decades, changes and structural shifts in the global economy have downsized the scope of union activity. In the concluding chapter of their anthology Varieties of Unionism, John Kelly and Carola Frege study the ongoing crisis of unions in the industrialised world and reflect on possibilities for their revitalisation. ${ }^{1}$ They posit that despite significant economic and political changes at national and international levels, trade unions remain key actors in the economic and political realms. A key aspect of their study is a focus on the impact of the decline of unions on civil society and politics. "Union decline threatens not only the collective regulation of industrial relations (safeguarding better wages, working conditions and job security), but also affects, if more indirectly, the quality of the broader civil society and political life by weakening one of its largest and most significant civil actors or, in the developing world, by not developing unions to support the growth of civil society, in playing a pivotal role in the growing resistance against corporate-led globalisation.”2

In turn, the analysis of the weakening of the workers' movement at the onset of the post civil war period and the process of state incorporation allows for a better understanding of the absent or at least scant cooperation between trade unions and civil society organisations in their mobilisation for change in post-war Lebanon. The challenges and current conditions of the civil society in Lebanon cannot be clearly understood without taking into account the repercussions of a tamed workers' movement represented by the General Confederation of Workers in Lebanon (GCWL) and its paralysis vis a vis civil society.

With this context in mind, this paper considers the part played by the organised workers' movement, represented by the GCWL and the League of public sector employees in the political and economic struggle for change in Lebanon in the early post-war period. The research examines the state and ruling elite weakening of the workers' movement, and their making use of the patrimonial character of state institutions.

The term "elite" is linked to a so-called normative value that judges the "quality" of the members of the ruling class. It is, therefore, necessary to recall the strict functional dimension of this term, at least in the way it is used in this research. Thus, the definition of "elite" refers to a limited group of individuals that hold more power (or influence) than others, this power being the real influence, indirectly or directly, on the politics and activity of the state. ${ }^{3}$ It is in this context that I aim to examine the role of the ruling elite.

\footnotetext{
${ }^{1}$ Carola Frege and John Kelly (eds.), Varieties of Unionism: Strategies for Union Revitalisation in a Globalising Economy, Oxford, Oxford University Press, 2004.

${ }^{2}$ Michael Morley, Patrick Gunnigle, and David Collings, Global Industrial Relations, London, Routledge, 2006, p. 221.

${ }^{3}$ Robert David Putnam, The Comparative Study of Political Elites, London, Prentice-Hall, 1976.
}

This paper was first published in the 3rd issue of the Civil Society Review: https://civilsocietycentre.org/resource/civil-society-review-issue-3-unraveling-\%E2\%80\%9Ccivilsociety\%E2\%80\%9D-policydependency-networks-and Published on Lebanon Support's Civil Society Knowledge Centre: https://civilsocietycentre.org/paper/understanding-state-incorporation-workers-movement-early-post-war-lebanonand-its-backlash 
To what extent did the state and the ruling elite tame the workers' movement by intervening in the country's institutional and legal framework? To what extent was the GCWL able to influence political and economic policies in Lebanon in the early post-war period?

\section{State-Labour Relations}

The sectarian political system in Lebanon has played a central role in shaping the trajectory of the labour movement. Time and again, it has halted the mobilisation of wage earners against the ruling elite and the state through the manipulation of sectarian and political affiliations as well as institutional and organisational conditions. The perpetuation of traditional social relations, the impact of sectarianism, political affiliations, and government intervention within the union structure all resulted in a divided movement, and generally cautious and moderate behaviour towards the government.

Following independence, the Lebanese state adopted restrictive legal provisions pertaining to the workforce and trade unions. In addition to predominant traditional familial and sectarian affiliations that curbed the development of a large and powerful labour movement, the state imposed restrictive regulations on the workforce and private sector trade unions. Lebanon did not ratify the International Labour Organisation (ILO) Convention No. 87 of 1948 on Freedom of Association and Protection of the Right to Organise seemingly because it did not want to allow for the development of strong trade unions capable of challenging state policies and elite interests. Article 2 of Convention No. 87 sanctifies the right of association without preauthorisation: "Workers and employers, without distinction whatsoever, shall have the right to establish and, subject only to the rules of the organisation concerned, to join organisations of their own choosing without previous authorisation." ${ }^{4}$ Convention No. 87 also provides that the procedures of union registration are limited and short in view of taming the conditions and procedures that might constitute an obstacle for the right of association. In 2012, the Minister of Labour Charbel Nahhas submitted to the council of ministers a draft law to allow for the ratification of Convention No. 87. Legislative Decree No. 8530 dated July 18, 2012 stipulated the submission of the draft law to the parliament, however, it had a major amendment: a reservation on the second article of the convention pertaining to the cancellation of the preauthorisation of unions. Article 2 is the main pillar of Convention No. 87, which shows that the government still insisted on the pre-authorisation provision despite its negative impact on workers. ${ }^{5}$

\footnotetext{
${ }^{4}$ International Labour Organisation, “Convention No. 87 of 1948 on Freedom of Association and Protection of the Right to Organise,” Website, International Labour Organisation, available at: http://www.ilo.org/dyn/normlex/en [last accessed 6 July 2018].

${ }^{5}$ Diana Kallas, “al-Qada' Yu'addi Dawr fi Himayat al-Hurriyyat al-Naqabiyya Raghma al-Thugurat alKanuniyya: Fahal Yastajib al-Musharri '”” Website, The Legal Agenda, 12 November 2012, available at: http://legal-agenda.com/makalat.php?katib=75 [last accessed 19 April 2018].
}

3

This paper was first published in the 3rd issue of the Civil Society Review: https://civilsocietycentre.org/resource/civil-society-review-issue-3-unraveling-\%E2\%80\%9Ccivilsociety\%E2\%80\%9D-policydependency-networks-and Published on Lebanon Support's Civil Society Knowledge Centre: https://civilsocietycentre.org/paper/understanding-state-incorporation-workers-movement-early-post-war-lebanonand-its-backlash 
In line with its abstention from ratifying the convention, the Lebanese Labour Code promulgated in 1946 explicitly limited freedom of association. The legal provisions in the Labour Code were characterised by the substantial role accorded to the state for the control of employment conditions and the management of trade union affairs. Initially, Article 50, as it appeared in the Labour Code of 1946, allowed the employer to dismiss any of its employees that are not subject to a contract or an agreement for a determined period of time. Article 50 was amended by Decree No. 9640 of February 1975. The amended Article 50 stipulates that the "dismissal of the members of a trade union council, duly elected, shall depend, during the period of their tenure, on recourse to the competent Conciliation Board". Therefore, the protection of unionists is limited to the elected board members of unions licensed by the Ministry of Labour. Consequently, the code does not protect union leaders during the founding period of the unions in question, that is, the period between the application for founding a union and the elections of the trade union council of representatives after receiving the authorisation of the Ministry of Labour. This period is usually the time when unionists need protection the most as unions are usually established when conflicts arise between workers and employers. $^{6}$

Furthermore, as specified in Article 86, “no employers' or wage earners' and salary-earners' trade union may be established except after due authorisation from the Ministry of National Economy."7 Surprisingly, the authorisation required for unions is not imposed on associations and political parties, which are not required to file an authorisation at the Ministry of Interior. In addition, the law does not specify a deadline for the Ministry of Labour to issue its decision regarding the authorisation. This leaves trade unions under the control of the minister in charge and at the mercy of political will, which means that a trade union's requests may end up sitting unapproved in the ministry drawers. Such restrictive legal provisions have proved to be major impediments to the flourishing of the labour movement, and they are still in place today. Eventually the code dealt with trade unions as threats to political stability and showed limited faith in free collective bargaining.

In addition to Labour Code restrictions on private sector trade unions, the law also constrained the association of public sector employees (including public sector teachers). According to Article 15 of Law Decree No. 112 issued on 12/6/1959, civil servants are forbidden from dealing with political affairs, joining a political party, or participating in strikes. Law No.144 issued on 6/5/1992 allowed civil servants to join political parties, but continued to prohibit their association with any trade union. According to Article 65 of Law Decree No. 112, a civil servant's participation in a strike is akin to a resignation, which clearly violates the freedom of association of workers.

\footnotetext{
${ }^{6}$ Ibid.

${ }^{7}$ Currently known as the Ministry of Labour.
}

4

This paper was first published in the 3rd issue of the Civil Society Review: https://civilsocietycentre.org/resource/civil-society-review-issue-3-unraveling-\%E2\%80\%9Ccivilsociety\%E2\%80\%9D-policydependency-networks-and Published on Lebanon Support's Civil Society Knowledge Centre: https://civilsocietycentre.org/paper/understanding-state-incorporation-workers-movement-early-post-war-lebanonand-its-backlash 
In 1972, Decision No. 335 gave the right to public primary school teachers to organise in leagues. Primary school teachers succeeded in securing their rights for organisation in elected leagues before secondary teachers, which was the result of a momentous teachers' mobilisation during the 1970s inflicting protracted pressure on the Ministry of Education to enact such a decision. Although Decision No. 335 gave the primary educational staff the right to organise under "cultural” leagues without any mention of a workers' association or trade union, teachers transformed the leagues into a demand platform in order to ameliorate their working conditions as well as the overall situation of public schools. Moreover, in 1993 the graduates of the Administration Institute, a state agency for administrative reform, were organised under one league, which became the League of Civil Servants in 2012.

In addition to legal constraints, the labour movement suffered from a problematic organisational structure. The GCWL charter promulgated in 1970, which remains unchanged in 2017, was controversial and considered to be behind the weakening of the labour movement. On April 30, 1958, the government authorised the establishment of the GCWL, consisting of four federations. ${ }^{8}$ The Confederation was inactive and included only right wing federations. The Ministry of Social Affairs did not authorise other federations, and therefore a large share of trade unions remained outside the GCWL. However, in 1966, the Ministry of Social affairs authorised five new federations of which a main left-wing federation, which adhered to the GCWL. ${ }^{9}$ It took until May 1970 to subsume all trade union federations under the GCWL which became the official negotiator for both public and private sector workers in Lebanon. The confederation was initially designed with a structure that aimed at reducing disagreements between rival federations stemming from political affiliations. Nevertheless, this structure lacked two key democratic features. First, the lower body did not elect the superior one: the council of representatives did not elect the executive council. Second, proportional representation of federations according to the total number of members was not applied, even though the size of the federations varied significantly. Consequently, the GCWL was subject to political intervention through electoral engineering: the proliferation of federations, mainly after the war, was largely due to the intent of the state to control the Confederation's decisionmaking.

In addition, the Confederation mainly relied on financial assistance from the government and foreign donor institutions, which might have had negative repercussions and implications on the labour movement in general, especially in terms of its independence. While many attempts to reform internal regulation have been made since the 1980s, those regulations remain, until today, unchanged.

\footnotetext{
${ }^{8}$ Federation of United Trade Unions; League of Trade Unions of Workers and Employees of the Lebanese Republic; Federation of Trade Unions of North Lebanon; Federation of Independent Trade Unions.

${ }^{9}$ National Federation of Trade Unions of Workers and Employees.
}

5

This paper was first published in the 3rd issue of the Civil Society Review: https://civilsocietycentre.org/resource/civil-society-review-issue-3-unraveling-\%E2\%80\%9Ccivilsociety\%E2\%80\%9D-policydependency-networks-and

Published on Lebanon Support's Civil Society Knowledge Centre: https://civilsocietycentre.org/paper/understanding-state-incorporation-workers-movement-early-post-war-lebanonand-its-backlash 
Economic factors also come into play in the post-civil war period. Liberal economic measures, the control of the ruling power elite, the prevalence of the tertiary sector, and the deteriorating productive sector all served to demarcate labour relations and shape the size and trajectory of the labour movement. Moreover, the core features of the labour market also hindered the advancement of the labour movement. Despite a fully-fledged reconstruction plan and pledged economic growth, the economic situation in post-war Lebanon did not improve as expected. While the target annual growth rate of the reconstruction programmes ${ }^{10}$ was around $8 \%$, the actual average rate for the period of 1993-2010 only reached around 4.5\% with major variations in different periods. ${ }^{11}$ It should be noted that the post-war annual growth rate was below the $6 \%$ growth rate average registered before the war, especially during the 1960s and the first half of the 1970 s. $^{12}$

Post-war reconstruction policies had severe repercussions on the private sector in terms of productivity and employment. In fact, $36 \%$ of the total credit of banks (equivalent of $90 \%$ of GDP) was assigned to the government in view of covering the state deficit. This deficit, which maintained high interest and borrowing rates, hampered access of the productive sector in particular and the private sector in general to necessary credits. A constant decrease of loans to the private sector emerged starting in 1999, going from $34 \%$ to $23 \%$. ${ }^{13}$ Around $65 \%$ of all loans in 1999 were dedicated to the sectors of construction and trade, while industry was allocated $10 \%$ of all loans and agriculture between $1 \%$ and $2 \%$. The industrial sector operated at $30-50 \%$ of its capacity. ${ }^{14}$ The monetary and fiscal policies clearly stymied the development of the productive sector and the private sector during the post-war period. Even though industry and agriculture were not traditionally strong holdings in pre-war Lebanon, these sectors could not be substituted in terms of job creation, equal redistribution of resources, or the establishment of strong pillars for a healthy economy.

The activity rate in Lebanon remained stagnant and low, resulting in a large share of the population being excluded from the regulated labour market and in turn from the labour movement: In 2004, the activity rate stood at 44\%, which was close to the rate in 1970 (45\%). Sectoral distribution of the workforce shows the predominance of workers in the services

\footnotetext{
${ }^{10}$ At the end of the war in 1990, the government designed a reconstruction strategy that aimed at reviving the traditional role of Lebanon as a regional trade and financial centre. This vision was clearly stated in the official reconstruction plan "Horizon 2000, for Reconstruction and Development" with a budget of USD 14.3 billion over a period of ten years between 1993 and 2002.

${ }^{11}$ Ministry of Finance, “Public Finance Yearly Report,” Beirut, Ministry of Finance, 2012, p.7, available at: http://www.finance.gov.lb/en-us/Finance/Rep-Pub/DRI-MOF/Public\%20Finance\%20Reports/YR_2011.pdf [last accessed: July 6, 2018]

12 Toufic Gaspard, A Political Economy of Lebanon, 1948-2002, Leiden, Brill, 2004.

${ }^{13}$ Marco Retting, "The Role of the Banking Sector in the Economic Process of Lebanon, before and after the Civil War,” Master Thesis, London, School of Oriental and African Studies, University of London, 2010, p.53.

${ }^{14}$ Sami E. Baroudi, "Continuity in Economic Policy in Postwar Lebanon: The Record of the Hariri and Hoss Government Examined, 1992-2000,” Arab Studies Quarterly 24, no. 1 (Winter 2002), p.63.
}

6

This paper was first published in the 3rd issue of the Civil Society Review: https://civilsocietycentre.org/resource/civil-society-review-issue-3-unraveling-\%E2\%80\%9Ccivilsociety\%E2\%80\%9D-policydependency-networks-and Published on Lebanon Support's Civil Society Knowledge Centre: https://civilsocietycentre.org/paper/understanding-state-incorporation-workers-movement-early-post-war-lebanonand-its-backlash 
sector (46\%) versus $8 \%$ in agriculture and $15 \%$ in industry in $2004 .^{15}$ In terms of labour demand, according to the 2004 "Census of Establishments", about 90\% of establishments employed less than five workers. ${ }^{16}$ The small size of the majority of enterprises - was accompanied with the limited capacity for association of workers in micro and small enterprises. Another factor affecting the size of the labour movement was the high share of informal employment, foreign workers, and domestic workers who were legally restricted from unionisation. These features of the workforce played a role in decreasing the share of unionised workers in the workplace. In view of the repercussions of the above-mentioned obstacles, the labour movement was not endowed with resilient pillars for growth and development.

\section{The Institutional Perspective}

This research assesses the impact of legal and institutional frameworks on labour relations in Lebanon. According to an institutional perspective, institutions are "formal or informal procedures, routines, norms and conventions embedded in the organisational structure of the polity or political economy. They can range from the rules of a constitutional order or the standard operating procedures of a bureaucracy to the conventions governing trade union behavior or bank-firm relations. In general, historical institutionalists associate institutions with organisations and the rules or conventions promulgated by formal organisation."17 Institutionalism considers the institutional structures of regimes to have different implications, particularly in terms of the political incorporation of various social structures.

Although they do not specifically focus on labour movements, the works of Eva Bellin are insightful for understanding labour relations in the Middle East. For Bellin, neither the weakness of civil society, nor the state's firm grip on the economy, poverty, or culture are satisfactory explanations for the Middle East's resistance to democratic transition. According to Bellin, other regions, which were similarly deprived succeeded in the transition to democracy.

"Why have the Middle East and North Africa proven exceptionally resistant to democratic transition, in marked contrast to other regions in the world? The answer, it argues, lies not in cultural or socio-economic factors but rather in the character of the Middle Eastern state, and most important the exceptional strength

\footnotetext{
${ }^{15}$ Central Administration of Statistics, "L'enquête par sondage pour la population active au Liban 1970”, Beirut, CAS, 1972, p. 103; Central Administration for Statistics, "Living Conditions of Households. The National Survey of Household Living Conditions,” Beirut, CAS, 2004, p. 58,

${ }^{16}$ Central Administration of Statistics, "Census of Establishments of 2004,” Beirut, Central Administration of Statistics, 2006, p.26.

${ }^{17}$ Peter Hall and Rosemary Taylor, "Political Science and the Three New Institutionalisms," MPIFG Discussion Paper, Cologne, Max-Planck-Institut für Gesellschaftsforschung, 1996, p. 6.
}

This paper was first published in the 3rd issue of the Civil Society Review: https://civilsocietycentre.org/resource/civil-society-review-issue-3-unraveling-\%E2\%80\%9Ccivilsociety\%E2\%80\%9D-policydependency-networks-and Published on Lebanon Support's Civil Society Knowledge Centre: https://civilsocietycentre.org/paper/understanding-state-incorporation-workers-movement-early-post-war-lebanonand-its-backlash 
and will of its coercive institutions to repress all democratic initiatives. Four factors explain the exceptional coercive capacity and will of the Middle Eastern state: The region's access to rent, the persistent support of international patrons, the patrimonial character of state institutions, and the limited degree of popular mobilisation for democratic reform." ${ }^{18}$

According to Bellin, a country's level of institutionalisation defines and determines the robustness of coercive apparatus in repressing reform initiatives. More precisely, a coercive apparatus coupled with a limited level of institutionalisation is fertile ground for patrimonialism, cronyism, a blurred distinction between public and private - leading to corruption and abuse of power - and discipline "that is maintained through the exploitation of primordial cleavages, often relying on balanced rivalry between different ethnic/sectarian groups." ${ }^{\prime 19}$ In these conditions, any political reform is perceived as a prospect of ruin for the elite of the coercive apparatus.

Bellin's analysis underlines the significance of reviewing structural factors and the character of state institutions when researching democratic transition and the prospects of democratic initiatives stemming from the labour movement. As previously mentioned, this research examines the effect of institutions - designed by a sectarian ruling elite - on the capacity of the sectarian elite to tame any reform initiatives including those that stem from the mobilisation of the labour movement.

This first section of this paper charts the demands and actions of the GCWL, and the interrelations among GCWL members, during a vigorous period between 1992 and 1997. The second section will highlight the major means of control and state incorporation of the labour movement in Lebanon.

\section{A Vigorous Labour Movement, 1992-1997}

Before the outbreak of the Civil War in 1975, the Confederation comprised eighteen federations. During the war period from 1975 to 1989, six new federations joined the Confederation and at that point the Confederation represented 156 trade unions. ${ }^{20}$ In 1992, the GCWL was presided by Antoine Bishara knowing that the last elections of the executive board were organised in $1981 .{ }^{21}$

\footnotetext{
${ }^{18}$ Eva Bellin, “Coercive Institutions and Coercive Leaders,” in Marsha Posusney and Michele Angrist (eds.), Authoritarianism in the Middle East: Regimes and Resistance, Boulder, Lynne Rienner Publishers, 2005, p. 21. ${ }^{19}$ Ibid., p. 28.

${ }^{20}$ My calculations are based on data collected from the Ministry of Labour.

${ }^{21}$ Antoine Bishara was President of the Federation of Unions of Independent Authorities and Public and Private institutions, one of the largest federations. He was the GCWL president for ten years (1983-1993).
}

8

This paper was first published in the 3rd issue of the Civil Society Review: https://civilsocietycentre.org/resource/civil-society-review-issue-3-unraveling-\%E2\%80\%9Ccivilsociety\%E2\%80\%9D-policydependency-networks-and Published on Lebanon Support's Civil Society Knowledge Centre: https://civilsocietycentre.org/paper/understanding-state-incorporation-workers-movement-early-post-war-lebanonand-its-backlash 
At the end of the war, the GCWL expressed its endorsement of the Ta' if Agreement and welcomed the economic and social provisions included in the accords, which focused on the need for balanced regional development as well as the establishment of the Economic and Social Council. In almost all key statements issued after the war, namely at the 1995 and 1996 GCWL conferences, the GCWL voiced its demand for the immediate implementation of the economic provisions of the agreement, notably the setting in motion of the Economic and Social Council.

The period between 1992 and 1997 was characterised by an energetic GCWL that repeatedly voiced demands for wage increases, a new salary scale, and fringe benefits. Its militant leadership, that was resolutely opposed to the reconstruction strategy of the government, mainly shaped the mobilisation of the Confederation. During this period the GCWL repeatedly demanded a minimum wage increase, which the cabinet approved three times in 1994, 1995, and 1996. The following are the key events of this period.

The elections of the first post-war executive board in summer 1993 witnessed the defeat of Antoine Bishara. Most of the independent and left-wing candidates won in the elections and Elias abu Rizq was elected President. ${ }^{22}$ Elias abu Rizk was an employee at the national television network Tele Liban. He was elected President of the Union of Tele Liban Workers and Employees and was later elected President of the Federation of United Trade Unions.

At that point the GCWL entered into dialogue with the Minister of Labour Abdallah al-Amin regarding a list of demands. ${ }^{23}$ In November 1993, the Ministry of Labour and the GCWL reached an agreement pertaining to wage increases, benefits, and price controls. But the government failed to respect the agreement. ${ }^{24}$ The following year, the GCWL reiterated its demands several times. In September 1994, it submitted a detailed declaration to the President, the Council of Ministers, and the parliament, presenting the demands for wage increases, workers' benefits, and regulations on rent control and consumer prices. In December 1994, the same package of demands was presented at the sixth session of the National General Conference of Trade Unions. The final document of the Conference repeated the demands for wage increases, additional worker benefits, enhancing control over consumer prices, a progressive taxation system, additional public spending on education and health services, a new salary scale for professors of the Lebanese University and school teachers, the establishing of the Economic and Social Council, as stipulated by the Ta'if Agreement, and the

\footnotetext{
${ }^{22}$ An-Nahar, July 9, 1993.

${ }^{23}$ Abdallah el-Amine was affiliated to the Baath party.

${ }^{24}$ Sami Baroudi, “Economic Conflict in Postwar Lebanon: State - Labor Relations between 1992 and $1997, "$ Middle East Journal, Washington DC, The Middle East Institute, 1998, Vol. 52 (4), p. 537.
}

9

This paper was first published in the 3rd issue of the Civil Society Review: https://civilsocietycentre.org/resource/civil-society-review-issue-3-unraveling-\%E2\%80\%9Ccivilsociety\%E2\%80\%9D-policydependency-networks-and

Published on Lebanon Support's Civil Society Knowledge Centre: https://civilsocietycentre.org/paper/understanding-state-incorporation-workers-movement-early-post-war-lebanonand-its-backlash 
endorsement of the prerogatives of the GCWL to name its representatives to the Economic and Social Council. ${ }^{25}$

The confrontation between the GCWL and the Hariri cabinet continued through 1995 as soon as Hariri was appointed to head his second cabinet on 25 May 1995. Following the pressure exerted by public sector employees, including public school teachers and Lebanese University professors, in July 1995 the government approved a 20\% wage increase for all public-sector employees. ${ }^{26}$ On 19 July 1995, the GCWL called for a general strike and demonstrations when the government decided to mainly finance the wage increase by imposing an additional charge of LBP 2,500 (USD 1.8) on every 20 litres of gasoline purchased. The government did not withdraw the gasoline tax and reacted by banning all demonstrations and public gatherings, calling upon the internal security forces and army to intervene. At this point, heavy criticism of the government was expressed by several officials, notably Speaker of the House Hussein alHusseini, and the former prime minister, Omar Karami. The prime minister was reproached for using the army to strengthen his power. ${ }^{27}$

In February 1996, the GCWL expressed its opposition to the economic and political policies of the government at the seventh session of the National General Conference of Trade Unions, an annual conference organized by the Confederation. This comprised a virulent attack on the government for its poor economic policies, public debt, trade and budgetary deficits, high interest rates, and the deterioration in workers' living conditions. In addition to this economic critique, the report also tackled political issues, criticising the new media law and the ban on demonstrations as a serious violation of the freedom of the people. The conference report presented the same GCWL demands as expressed in previous National Trade Union Conferences. It set a one-month ultimatum for the government to address the list of demands before calling for a general strike and mass demonstrations. ${ }^{28}$

In February 1996, public school teachers and Lebanese University professors held strikes demanding the implementation of a new salary scale. ${ }^{29}$ In the same month, the GCWL called for a national general strike and anti-government demonstrations on the $29^{\text {th }}$ of February. In reaction to this call, the government once again banned all demonstrations while the army

${ }^{25}$ General Confederation of Workers in Lebanon, "Taqrir Mu'tamar al-Naqabi al-Watani al- 'Am 1994," Beirut, General Confederation of Workers in Lebanon, 13 December 1994, p. 3.

${ }^{26}$ An-Nahar, “Al-Mu‘allimun Yuwasilun al-Idrab wa 90 Alf Talib ‘Aliqun,” An-Nahar, 8 July 1995, p. 1, 16.

27 As-Safir, "Mawaqif Niyabiyya Tantaqid Muqarrarat Majlis al-Wizara’ al-Akhira,” As-Safir, 27 October 1995, p. 3.

${ }^{28}$ General Confederation of Workers in Lebanon, op. cit.; As-Safir, "Jam'iyya 'Umumiyya wa lika'at Manatiqiyya Litanfidh al-Idrab fi 27 al-Hali,” As-Safir, 7 February 1996, p. 6.

${ }^{29}$ As-Safir, "Al-Hiwar al-Maqtu“ Yadfa‘ 60 Alf Ustadh ila Idrab Tahziri fi Intizar Akhir Shubat,” As-Safir, 13 February 1996, p. 1, 10.

10

This paper was first published in the 3rd issue of the Civil Society Review: https://civilsocietycentre.org/resource/civil-society-review-issue-3-unraveling-\%E2\%80\%9Ccivilsociety\%E2\%80\%9D-policydependency-networks-and Published on Lebanon Support's Civil Society Knowledge Centre: https://civilsocietycentre.org/paper/understanding-state-incorporation-workers-movement-early-post-war-lebanonand-its-backlash 
imposed a curfew the day of the declared strike. ${ }^{30}$ The GCWL retreated and cancelled the strike 11 hours before it was due to start in order to avoid clashes with the army. As discussed in the following section, the GCWL showed a tendency to call off strikes at the last minute in response to government promises or pressure.

Following this episode, Hariri and Elias Abu Rizqdid in fact met to discuss prior events, as Hariri appeared to be willing to take into account some of the voiced criticism of his economic programme. ${ }^{31}$ Abu Rizq visited the Prime Minister in his residence, where he reiterated the Confederation's demands. In March 1996, business leaders revealed they were ready to discuss labour demands and wage increases. Consequently, the price index committee ${ }^{32}$ held a set of meetings in March 1996 to identify the price increase of basic goods and services in 1995 and to determine the adjustment to the cost of living to be applied for $1996 .{ }^{33}$ While the GCWL demanded a $76 \%$ wage increase, business representatives offered nothing more than $15 \%$. At this point, the committee suspended its meetings. ${ }^{34}$ In reaction to the government's silence and inaction, the GCWL decided to use the upcoming visit of the French president Jacques Chirac as a pressure tool against the government and therefore issued an ultimatum: the government would answer the workers' demands at once or the workers would organise a sit-in in front of the parliament coinciding with President Chirac's speech on 6 April 1996. Throughout that day, the Lebanese army ensured that the entrance to the headquarters of the GCWL remained blocked and prevented those inside from marching to the parliament. ${ }^{35}$ Instead, the sit-in was held inside the headquarters and was covered by the local media.

In April 1996, Israel launched “Operation Grapes of Wrath” against Lebanon, conducting extensive shelling for 16 days in what it claimed was an attempt to stop rocket attacks from Hezbollah. Following the April War, the government approved a scheme for wage increases and other benefits for workers in the private sector in May 1996.

On one side, business associations rejected the scheme, arguing that it would lead to financial burdens. Business associations include the Chambers of Commerce, trade associations, and the bank association who are expected to take part in the dialogue with the GCWL regarding wage

${ }^{30}$ As-Safir, “Majlis al-Wuzara’ Yu’akkid Qarar Mani` al-Tazahur wa Yukallif al-Jaysh Dabt al-Amn Limudatt 3 Ashhur," As-Safir, 28 February 1996, p. 3.

${ }^{31}$ As-Safir, Ghasib al-Mukhtar, “Al-Hukuma Tuqarrir I‘adat Tartib Awlawiyataha,” As-Safir, 10 February 1996, p. 2.

${ }^{32}$ The Price Index Committee includes representatives of business associations, the GCWL, and the Ministry of Labour to determine annual wage increases in line with the increase of costs of goods and services.

${ }^{33}$ Imad Marmal, “Taqriran Hawla Waqa’i“ wa Asda’ Lika’ al-Hariri - Abu Rizq,” As-Safir, 13 March 1996, p. 3.

${ }^{34}$ An-Nahar, “Al-‘Ummal Yulawihoun Takraran bi al-’Idrab wa al-Hiwar Yusabiq Nihayat Adhar,” An-Nahar, 27 March 1996, p. 1.

${ }^{35}$ Rita Sharara, "Birri: Harriy Tawjih al-I‘tissam Dodd al-Hukuma la Dodd Ziyarat Chirac,” An-Nahar, 4 April 1996, p. 2.

11

This paper was first published in the 3rd issue of the Civil Society Review: https://civilsocietycentre.org/resource/civil-society-review-issue-3-unraveling-\%E2\%80\%9Ccivilsociety\%E2\%80\%9D-policydependency-networks-and Published on Lebanon Support's Civil Society Knowledge Centre: https://civilsocietycentre.org/paper/understanding-state-incorporation-workers-movement-early-post-war-lebanonand-its-backlash 
increase related demands at least within the Consumer Price Committee. ${ }^{36}$ It should however be noted that it became rather common for the Lebanese political class to encompass wealthy businessmen who represented the interests of the business-financial elite. This became an inherent part of the political formation of post-war Lebanon and its relation with an "ultraliberal” economic model, which overlapped between the interests of the business-financial elite and the ruling political elite. Many examples of deputies and ministers who would later on become rich proved the enmeshed economic and political arenas. ${ }^{37}$ A study by Joseph Bahout on the professional background of deputies elected to the parliament in 1996 showed that the largest share of deputies in fact belonged to the category of businessmen (30\%) - this category included entrepreneurs, bankers, traders, industrialists, etc. - followed by lawyers and doctors. $^{38}$

The GCWL, meanwhile, rejected the scheme as it fell significantly below the requested $76 \%$ increase. In addition, public sector teachers organised strikes and demanded a new salary scale for public sector employees. To increase the pressure, they also suspended the grading of official baccalaureate exams, leaving 60,000 students stranded without grades. ${ }^{39}$ Another action followed, and an usual one in the trajectory of the Confederation, whereby the GCWL and the teachers' leagues threatened to instruct their supporters to vote against pro-government deputies in the elections of the summer of 1996 unless the parliament approved the new salary scale for public school teachers. ${ }^{40}$ Following this immense pressure, the salary scale and most of the teachers' demands were approved by parliament. The main pressure stemmed from the action of the Teachers' Bureau, which gathered both public and private sector teachers, and relied on strikes and the suspension of the grading of official exams. ${ }^{41}$

In the immediate aftermath of the parliamentary elections that took place on 25 September 1996, Elias Abu Rizq attacked the government once again. During a political gathering of leaders opposing the Hariri cabinet, Abu Rizq launched a virulent critique of the government's plans to close down almost all private television and radio stations. ${ }^{42}$ He also repeated all the

\footnotetext{
${ }^{36}$ Decree No. 4206 of August 8, 1981 stipulates the creation of the Price Index Committee composed of representatives of workers and business associations. Law 36/67 date 16/5/1967 stipulates that the Government of Lebanon is bound to publish, through the Price Index Committee, a yearly cost of living index.

${ }^{37}$ Joseph Bahout and Chawki Douayhi, La vie publique au Liban, expressions et recompositions du politique, Les Cahiers du CERMOC 18, Beirut, CERMOC, 1997, p. 24.

${ }^{38}$ Ibid.

39 An-Nahar, "Maktab al-Mu‘allimin Yukarrir Ta‘liqahu al-Tasshih Raythama Tanjali al-Ta‘ahudat aan alNata'ij," An-Nahar, 2 August 1996, p. 19; An-Nahar, "Maktab al-Mu'allimin ma zal Mawqifahu 'an la Tasshih illa bi al-Silsila”, An-Nahar, 7 August 1996, p. 19.

${ }^{40}$ An-Nahar, "Hay'at al-Tansiq: Linussawit Dodd man Salabuna Luqmat al-'Aysh wa Fursat al-'Amal wa alSakan wa al-Musstashfa,” An-Nahar, 8 August 1996, p. 8.

${ }^{41}$ An-Nahar, "Iqrar Silsilat al-Mu'allimin wa Ihalat Baqiyat al-Muwazzafin 'ala al-Majlis al-Muqbil,” An-Nahar, 14 August 1996, p. 9.

${ }^{42}$ The national gathering (Al-Lika' al-Watani) was a meeting of opposition leaders including Hussein al-Husseini, Salim al-Huss, and representatives of the Phalangist party and the Lebanese Communist party.
}

12

This paper was first published in the 3rd issue of the Civil Society Review: https://civilsocietycentre.org/resource/civil-society-review-issue-3-unraveling-\%E2\%80\%9Ccivilsociety\%E2\%80\%9D-policydependency-networks-and Published on Lebanon Support's Civil Society Knowledge Centre: https://civilsocietycentre.org/paper/understanding-state-incorporation-workers-movement-early-post-war-lebanonand-its-backlash 
workers' demands voiced previously by the GCWL, and declared the readiness of the Confederation to call for strikes and mass demonstrations against the government's violation of freedom of speech and the media. ${ }^{43} \mathrm{~A}$ few days later, and despite the government ban, Abu Rizq called for a sit-in across the government headquarters on 4 October and a general strike and mass demonstrations on 10 October. As usual, the army intervened to prevent the scheduled sit-in and ban the demonstrations.

On 7 November, Hariri formed his third cabinet and on 28 November 1996, the GCWL again tried to organise demonstrations against the media ban as well as the poor economic and social conditions. Unsurprisingly, the demonstrations were violently thwarted by the army.

\section{From State Repression to State Incorporation}

The following section focuses on state repression of the labour movement through legal and structural manipulation. The state's intervention in the labour elections aimed at ousting the president of the GCWL and therefore weakening its opposition to state decisions and policies. The ruling elite's intervention relied on the political and sectarian affiliations of trade unionists in shaping the elections: the GCWL members - representatives of federations - voting behaviour was shaped by clear instructions from the political parties. These elections, like previous and following ones, were more a reflection of political alliances, tensions, and conflicts than a manifestation of workers' conditions and demands.

Following on from the GCWL's attempts at demonstrations in November 1997, Prime Minister Rafiq Hariri and Speaker of the House Nabih Berri decided to attack the GCWL leadership. Hariri and Abu Rizq had a long-standing tense relationship. As mentioned earlier, Abu Rizq enjoyed close relations with the political opposition to Hariri, mainly with Hezbollah and the Lebanese Army's commander-in-chief, Emile Lahoud, who was in continuous political disagreement with Hariri. ${ }^{44}$ At the beginning of 1997, Hariri attempted to halt the promotion of six colonels, including Jamil al-Sayyid, who was close to the Syrian regime, and Lahoud. Following Syrian pressure, Hariri was forced to allow the promotion. In turn, the 1997 GCWL elections were an occasion for Hariri to counter the increasing power of Lahoud through a campaign against the election of Abu Rizq. Hariri rallied opponents of Lahhud and the army, including Berri and Assaad Hardan, the labour minister. He also assembled trade unionist leaders who had previously clashed with Abu Rizq, such as Antoine Bishara.

Berri and Abu Rizq were also political rivals. In the 1996 parliamentary elections, Hardan, who was on Berri's list, competed with Abu Rizq, who was on the opponent list, over the same orthodox seat in the Hasbaya-Marjayun electoral area. The following year, Berri and Abu Rizq

\footnotetext{
${ }^{43}$ An-Nahar, "Birri Yatawaqa' Hallan Mutawazinan lil I'lam wa al-Lika’ al-Watani Yulawwih bi al-Idrab wa alTazahur,” An-Nahar, 26 September 1996, p. 1, 16.

${ }^{44}$ Sami Baroudi, op. cit., p. 543.
}

This paper was first published in the 3rd issue of the Civil Society Review: https://civilsocietycentre.org/resource/civil-society-review-issue-3-unraveling-\%E2\%80\%9Ccivilsociety\%E2\%80\%9D-policydependency-networks-and Published on Lebanon Support's Civil Society Knowledge Centre: https://civilsocietycentre.org/paper/understanding-state-incorporation-workers-movement-early-post-war-lebanonand-its-backlash 
clashed again, as the GCWL executive council opposed the admission of five new federations ${ }^{45}$ that were politically affiliated to the Amal Movement headed by Berri. ${ }^{46}$ The confrontation between Hariri and Abu Rizq reflected a conflict related to the balance of power within the post-war sectarian political system, rather than a conflict between workers, trade unions, and the state. This confrontation, however, led to the weakening and fragmentation of the labour movement.

In early 1997, Hardan launched a campaign against Abu Rizq aimed at toppling him at the next GCWL elections, which were to take place in April 1997. It is important to note that during the term of Abu Rizq, the Ministry of Labour withheld its LBP 500 million (USD 330,000) annual budget allocation to the GCWL and only transferred the outstanding sum upon the election of a new executive council later the same year. ${ }^{47}$

During this period, the Ministry of Labour was accused of intervening in the elections of several federations in order to guarantee pro-Amal representatives in the GCWL executive council. This aimed at guaranteeing a majority of votes against Abu Rizq. Indeed, on 13 April 1997, the elections of the Federation of the Workers of South Lebanon were the subject of widely documented government intervention. ${ }^{48}$ Newspapers reported heavily on the rigged elections. After these results, critics warned against similar government intervention in the upcoming GCWL elections. ${ }^{49}$ These federation elections resulted in five pro-government delegates on the executive council that would vote against Abu Rizq.

Moreover, a few days before the GCWL elections, the Ministry of Labour authorised the creation of five new federations, despite their rejection by the GCWL. These authorisations secured ten additional pro-government delegates in the executive council. ${ }^{50}$ These five newly authorised federations had not been admitted to the GCWL during the previous four years. The GCWL had required that the five federations submit additional documents in order to complete their applications. ${ }^{51}$ In other words, these federations had not been rejected. According to the internal regulations of the Confederation, the admittance of new federations required a two-

\footnotetext{
${ }^{45}$ Federation of Workers in Metal, Mechanics and Electricity; Lebanese Federation of Taxi Drivers and Transport Authorities in Lebanon; National Federation of Workers and Employees in South Lebanon; Federation of Jabal 'Amil for Agricultural Workers.

${ }^{46}$ The Amal Movement was founded in 1974 as the "Movement of the Dispossessed." Amal is associated with the Shiite community and is represented in the parliament by 13 deputies (2016). Nabih Berri has been the chairman of Amal since 1980 and president of the parliament since October 1992.

${ }^{47}$ Issam Al-Jurdi, “Hal Taftah Istikalat al-Zughbi Ma‘rakat al-Hayykaliyyat li I‘adat al-Tawhid?”, An-Nahar, 13 May 1998, p. 6.

${ }^{48}$ This federation would also be subject to divisions. On May 11, 1997, despite the elections that took place on April 13, the federation would witness the election of a second executive council.

${ }^{49}$ As-Safir, “Al-Qiyada al-‘Ummaliyaa: ‘Iddat al-Ma'raka Taktamil,” As-Safir, 17 April 1997, p. 1, 15.

${ }^{50}$ Rula Baydoun, “Al-Haraka al-‘Ummaliyya: Min al-Nidal li al-Wihda ila Daya 'Wihdat al-Nidal,” An-Nahar, 15 May 1997, p. 9.

${ }^{51}$ As-Safir, “Al-Qiyada al-‘Ummaliyaa: ‘Iddat al-Ma‘raka Taktamil,” op. cit., p. 1, 15.
}

This paper was first published in the 3rd issue of the Civil Society Review: https://civilsocietycentre.org/resource/civil-society-review-issue-3-unraveling-\%E2\%80\%9Ccivilsociety\%E2\%80\%9D-policydependency-networks-and Published on Lebanon Support's Civil Society Knowledge Centre: https://civilsocietycentre.org/paper/understanding-state-incorporation-workers-movement-early-post-war-lebanonand-its-backlash 
thirds vote by the executive council and the council of representatives. Once rejected, the federations in question could resort to the judiciary. The Ministry of Labour was not entitled to impose the admittance of federations to the Confederation. According to the Labour minister, the Ministry relied on Articles 93 and 94 of the Labour Code, ${ }^{52}$ in addition to two judiciary consultations. ${ }^{53}$ As mentioned earlier, these federations applied for membership to the GCWL four years prior to the April 1997 elections, but the Ministry of Labour only intervened four days before election day, which drew attention to the role and intervention of the government in the April 1997 elections.

The five newly licensed federations had clear political and sectarian affiliations to Nabih Berri's Shiite Amal Party. Bassam Tlays, president of the Workers' Bureau within the Amal Movement even acted as a spokesperson for these five federations, which was a clear indication of their political allegiance. The federations were licensed a few days before the elections of the GCWL executive council and were to participate in these elections despite the Confederation's rejection of their membership. ${ }^{54}$

The 22 member federations of the GCWL, plus the five newly authorised ones, participated in the elections of 24 April 1997. ${ }^{55}$ Out of the 27 federations, 11 were opposed to the GCWL leadership of the time. These were the five new federations and the six federations that had boycotted the GCWL: the federations of bank employees, aviation employees, independent authorities, maritime workers, the league of trade unions, and the federation of food products and leisure.

On 24 April 1997, two different elections for the GCWL executive bureau took place, and several irregularities were recorded. The first election was held at GCWL premises in the absence of representatives from the Ministry of Labour, which refused to undertake its

\footnotetext{
${ }^{52}$ Article 93 of the Labour Code: “An application for membership is presented to the trade union committee together with the applicant's identity card, and a work certificate approved by the Social Affairs Services and indicating that the applicant continues to exercise the profession represented by the trade union. Within fifteen days the trade union committee must decide by secret ballot whether the applicant is to be admitted or refused"; Article 94: "The applicant may object to the refusal decision before the Social Affairs Service which then adjudicates his case." See: Argus de la Législation Libanaise, "Code of Labour. A Comprehensive English Translation of the Lebanese Labour Code," Beirut, Bureau de Documentation Libanaise et Arabe, 2010, Volume 56 (1), p. 1-28. During an interview, Elias Abu Rizq pointed out that these articles refer to the admittance of working individuals and not to federations and therefore were irrelevant to that case.

53 “Al-Qiyada al-‘Ummaliyaa: 'Iddat al-Ma'raka Taktamil,” op. cit., p. 1, 15.

54 “Al-Qiyada al-‘Ummaliyaa: 'Iddat al-Ma‘raka Taktamil,” op. cit., p. 1, 15.

55 An-Nahar, "Muwajaha Qiyassiya al-Yawm Tuqarrir Mustaqbal al-Ittihad al-‘Ummali,” An-Nahar, 24 April 1997, p. 1, 12. The GCWL executive bureau refused to submit the list of federation delegates to the executive council as requested by the Ministry of Labour based on Decree number 52/7993, in order to supervise the elections. Therefore, one day before the elections, the Ministry published the list of delegates of the 27 delegations eligible to participate in the bureau elections. However, it is important to note that during the 1993 elections, the GCWL did not submit the list of delegates to the Ministry of Labour but only revealed it to its representatives on the day of the elections.
}

15

This paper was first published in the 3rd issue of the Civil Society Review: https://civilsocietycentre.org/resource/civil-society-review-issue-3-unraveling-\%E2\%80\%9Ccivilsociety\%E2\%80\%9D-policydependency-networks-and Published on Lebanon Support's Civil Society Knowledge Centre: https://civilsocietycentre.org/paper/understanding-state-incorporation-workers-movement-early-post-war-lebanonand-its-backlash 
observation prerogatives. Delegates from 12 federations loyal to Abu Rizq re-elected him as president. Out of the 26 delegates that attended these elections, 24 voted for Abu Rizq. ${ }^{56}$ According to the accounts of some delegates, these elections witnessed the heavy presence of security officers, who prevented some participants from entering the premises. ${ }^{57}$

One hour later, in the same building, another round of elections was held under the supervision of the Ministry of Labour, and broadcast on national television. The five newly licensed federations attended the elections. According to the Ministry of Labour, 35 delegates out of 54 voted for 12 pro-government members of the bureau with Ghanim al-Zoghbi as president. ${ }^{58}$ Al-Zoghbi had participated in trade union activities since 1964 within the Trade Union of Workers and Employees of Water Authorities in Lebanon. He took part in the establishment of the Federation of Trade Unions of Independent Authorities and Public and Private Institutions, of which he became Secretary General and later its representative on the GCWL executive council. $^{59}$

These elections marked the first explicit split in the labour movement despite its resilience to division during the Civil War. The division of the Confederation was the result of state intervention and corruption in the elections through the manipulation of legal provisions. Unsurprisingly, the Ministry of Labour recognised the results of the second elections and communicated its recognition to international and Arab organisations. The newly elected leadership paid a protocol visit to the President of the Republic Elias Hrawi, Prime Minister Rafiq Hariri, and Speaker of the Parliament Nabih Berri. ${ }^{60}$

However, Abu Rizq continued to claim the presidency. At the close of the elections, Abu Rizq declared his own victory while internal security forces halted media coverage. He was soon supported by political figures, notably government opponents, including the former prime minister Salim al-Hoss. ${ }^{61}$ The member of parliament Mustafa Saad, Hezbollah, the Lebanese Communist Party, and the Communist Action Organisation together published a communiqué supporting Abu Rizq in his election victory and denouncing government intervention. ${ }^{62}$ This was followed by the support of representatives of the ILO, the International Federation of Arab

\footnotetext{
56 An-Nahar, “Ittihad al-Mu‘arada...wa Ittihad al-Muwalat,” An-Nahar, 25 April 1997, p. 1, 18.

${ }^{57}$ Rula Baydoun, op. cit, p. 9.

58 Ibid.

59 An-Nahar, “Al-Hrawi La Yumani‘ fi Muadara Niyabiyya Litqassir Wilayat al-Majliss 4 Ashhur,” An-Nahar, 29 April 1997, p. 1, 20.

60 Ibid.

${ }^{61}$ Ibid., extract translated by the author: "What happened in the elections was very disappointing and has led, as expected, to the dangerous split of the labour movement. All this is due to the clear and unjustified interference of the government in these elections and its direct support for one party against another."

${ }^{62}$ Nabil Nasser, “Linakun Wahidan fi Istiqbalihi,” An-Nahar, 26 April 1997, p. 5.

This paper was first published in the 3rd issue of the Civil Society Review: https://civilsocietycentre.org/resource/civil-society-review-issue-3-unraveling-\%E2\%80\%9Ccivilsociety\%E2\%80\%9D-policydependency-networks-and

Published on Lebanon Support's Civil Society Knowledge Centre: https://civilsocietycentre.org/paper/understanding-state-incorporation-workers-movement-early-post-war-lebanonand-its-backlash 
Unions, and the International Federation of Free Unions in Brussels, which also denounced the poor conditions surrounding the electoral process. ${ }^{63}$

Briefly, these elections were marked by the intervention of the government on a legal and organisational level to curb the forces opposed to it within the GCWL. Hariri adopted a staunch position against the Confederation, as he feared it would hamper his economic reform plan. Between 1992 and 1997, the Confederation and the Hariri cabinets clashed over several demands, namely wage adjustments, consumer price control, and the independence of the labour movement. Hariri also reacted to the fact that the Confederation took positions and action in the political realm, which was not common behaviour for the GCWL.

State-labour relations during Elias Abu Rizq's term as GCWL president between July 1993 and April 1997 were highly confrontational. Under his leadership, the GCWL questioned and challenged almost every policy of the three Hariri cabinets. Hariri was determined to prevent the GCWL from imposing concessions on the government and therefore mobilised all available resources against Abu Rizq, including government intervention in elections with the support of the judiciary branch, which validated the victory of his rival Ghanim al-Zoghbi. ${ }^{64}$

Following the 1997 elections, the GCWL leadership would be tamed. Abu Rizq would surprisingly seize the presidency again in the 31 July 1998 elections but would no longer be able to pose any major challenge. On 15 March 2001, 47 out of 74 members of the executive council participated in the elections and voted unanimously for Ghassan Ghusn as president and Bassam Tlays as vice president. Ghassan Ghusn was then president of the Federation of Aviation Workers and close to the Amal Party, while Bassam Tlays was president of the Workers' Bureau at the Amal Movement. Ghusn would remain president of the GCWL until 2016. Under his leadership, the GCWL would be characterised by its weakness and timid actions.

\section{Means of State Control}

The state and the ruling elite worked on taming trade unions and blocking their opposition to socio-economic policies as well as their repeated sets of demands. The major tool of the ruling elite in their relations with the GCWL was intervention at institutional and organisational

63 "Ittihad al-Mu'arada...wa Ittihad al-Muwalat,” op. cit., p. 1, 18; "Al-Hrawi La Yumani` fi Muadara Niyabiyya Litqassir Wilayat al-Majliss 4 Ashhur," op. cit., p. 20, extract translated by the author: Hassan Jammam, representative of the International Federation of Arab Unions: "What happened during these elections aims to destroy the labour movement and I have never seen such interference during my 25 years of union practice," and Georges Martinez, director of the legal department at the International Federation of Free Trade Unions: "I just witnessed the worst aggression against democracy and union freedom which has ever occurred in any democratic state (...)."

${ }^{64}$ An-Nahar, “Al-Hariri Yattahim 'Alannan al-Ajhiza bi al-Taddakhul fi Intikhabat al-'Ummal,” An-Nahar, 24 July 1997, p. 1, 19. During a television interview in 1997, Rafiq Hariri revealed for the first time that the security forces had intervened in GCWL elections.

This paper was first published in the 3rd issue of the Civil Society Review: https://civilsocietycentre.org/resource/civil-society-review-issue-3-unraveling-\%E2\%80\%9Ccivilsociety\%E2\%80\%9D-policydependency-networks-and Published on Lebanon Support's Civil Society Knowledge Centre: https://civilsocietycentre.org/paper/understanding-state-incorporation-workers-movement-early-post-war-lebanonand-its-backlash 
levels including the withholding of the budget allocated to the GCWL, interference in executive council elections, and the excessive authorisation of federations of specific political affiliation.

\section{Withholding of the budget allocation}

During the terms of Abu Rizq's leadership of the GCWL, the budget allocation of the Ministry of Labour to the GCWL was withheld as mentioned earlier, and only released after the departure of Abu Rizq in 2000. This was a key tool in weakening the GCWL in order to tame its actions against the government.

\section{Intervention in GCWL Elections: Divide and Rule}

The government resorted to the old tactic of divide and rule. During every GCWL election, the government intervened in one way or another. In 1993, the government sided with the coalition of Antoine Bechara against Elias Abu Rizq. Following this, the Ministry of Labour intervened in every election of the executive council by requiring the submission of the electoral roll and the list of candidates prior to the elections. Legal provisions regulating trade unions do not stipulate this practice. The failure to submit these election details by the GCWL was usually followed by the Ministry of Labour refraining from validating the results of the elections. For instance, the Ministry of Labour refused to validate the elections in 1997. This intervention in the electoral process and its results facilitated the election of pro-government candidates and also led in some instances to a split in the Confederation, as was the case between 1997 and 1999.

\section{Authorisation of New Federations}

The main tool used by the ruling elite through the Ministry of Labour was the excessive authorisation of federations. In their study on the workers' movement in Lebanon, Badran and Zbib observed the creation of additional trade union federations in a process they describe as "hatching." ${ }^{65}$ According to Badran and Zbib, political parties such as the Baath party and the Syrian Social Nationalist Party were actively trying to increase their influence on the workers movement in the post civil war period. ${ }^{66}$ Bechara and Abu Rizq tried to prevent the admission of new federations, aware that the government was trying to achieve a pro-government majority within the GCWL executive council. The absence of proportional representation facilitated this task: each federation had two representatives in the GCWL council regardless of its size. While the communist party maintained its traditional presence in the committee, other parties linked to former militia leaders and close to the Syrian regime gained a majority of the

65 Ismail Badran and Mohamad Zbib, "Al-Ittihad Al-'Ummali Al-'Am Fi Lubnan,” Beirut, Friedrich Ebert Stiftung, 2004.

${ }^{66}$ Ibid.

This paper was first published in the 3rd issue of the Civil Society Review: https://civilsocietycentre.org/resource/civil-society-review-issue-3-unraveling-\%E2\%80\%9Ccivilsociety\%E2\%80\%9D-policydependency-networks-and

Published on Lebanon Support's Civil Society Knowledge Centre: https://civilsocietycentre.org/paper/understanding-state-incorporation-workers-movement-early-post-war-lebanonand-its-backlash 
votes. ${ }^{67}$ The number of federations in the GCWL kept increasing after 1997 from 22 in 1993 to 36 in 2001to 59 in $2015 .{ }^{68}$

\section{Conclusion}

This research focused on the centrality of the labour movement in the political and economic struggle for change. The decline of the organised labour movement does not imply that class struggle is no longer relevant, although this is the explanation adopted by those who prefer to privilege other factors such as identity, and citizenship. It rather means that capital and state have been winning this struggle. While structural changes in the global economy significantly hampered the activity and scope of associational power, trade unions remain important actors in the economic and political realms and scholars continue to study their possible revitalisation. The continuous attempts by the state and ruling elite to undermine the labour movement are evidence that a resilient and vigorous labour movement constitutes an imperative menace to the political system in place in Lebanon.

Finally, in addition to the use of force, the ruling elite has recently adopted the same tactics and lines of attack that it had employed to tame the GCWL in the 1990s, to fragment and weaken the mobilising project of public sector workers between 2011 and 2015. The head of the Union Coordination Committee, Hanna Gharib, was toppled in the 2015 elections of the secondary teachers' league, which was the backbone of the mobilisation. The elections of the board of public secondary school teachers league were subject to the manipulation of sectarian identities and political affiliation of teachers whereby almost all political parties allied together to give strict instructions to teachers' representatives to vote for their candidates. Through the same strategy, in July 2017, Ni'mi Mahfud, the president of the private sector teachers' union, was toppled in the union's elections.

The importance of studying state incorporation of the labour movement resides in its detrimental repercussions on civil society. With state incorporation, the GCWL was sidelined from agenda setting and negotiations with state and business associations within the policy making realm. Instead, it is political leaders within the state who take the duty to negotiate and set work related policy coupled with a quasi complete silence from trade unions and federations. This paralysis of the workers' movement cannot but ensue the weakening of the civil society. An effective civil society in Lebanon today hinges on the revival of the workers' movement in its organisation, mobilisation, and forceful participation in policy making.

\footnotetext{
${ }^{67}$ Hannes Baumann, “Citizen Hariri and Neoliberal Politics in Postwar Lebanon,” PhD thesis, London, School of Oriental and African Studies, University of London, 2012.

${ }^{68}$ Ibid.
}

19

This paper was first published in the 3rd issue of the Civil Society Review: https://civilsocietycentre.org/resource/civil-society-review-issue-3-unraveling-\%E2\%80\%9Ccivilsociety\%E2\%80\%9D-policydependency-networks-and

Published on Lebanon Support's Civil Society Knowledge Centre: https://civilsocietycentre.org/paper/understanding-state-incorporation-workers-movement-early-post-war-lebanonand-its-backlash 


\section{References}

An-Nahar, “والتظاهر بري يتوقع حلا متوازنا للاعلام واللقاء الوطني يلوح بالإضراب" An-Nahar, 26 September 1996.

An-Nahar, “هيئة التنسيق النقابية: لنصوت ضد من سلبونا لقمة العيش وفرصة العمل والسكن والستثنفى, AnNahar, 8 August 1996.

An-Nahar, “الهراوي لا يمانع في مبادرة نيابية لتقصير ولاية المجلس ع انهر," An-Nahar, 29 April 1997.

An-Nahar, “الحريري يتهم علنا الاجهزة بالتندل في انتخابات العمال," An-Nahar, 24 July 1997.

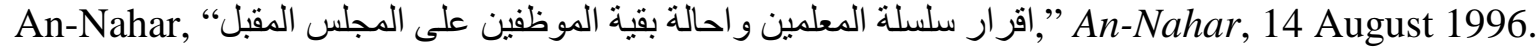

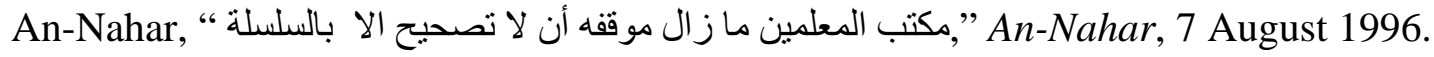

An-Nahar, “مو اجهة قاسية اليوم تقرر مستقبل الاتحاد العمالي,” An-Nahar, 24 April 1997.

An-Nahar, “المعلمون يو اصلون الاضر اب و •9 الف طالب عالقون,, An-Nahar, 8 July 1995.

An-Nahar, “و اتحاد للمو الات ... اتحاد للمعارضة؛" An-Nahar, 25 April 1997.

An-Nahar, “العمال يلوحون تكر ارا بالاضر اب و الحوار يسابق نهاية اذار," An-Nahar, 27 March 1996.

An-Nahar, “مكتب المعلمين يكرر تعليقه التصحيح ريثما تنجلي التعهدات عن نتائج), An-Nahar, 2 August 1996.

Argus de la Législation Libanaise, "Code of Labour. A Comprehensive English Translation of the Lebanese Labour Code," Beirut, Bureau de Documentation Libanaise et Arabe, 2010, Volume 56 (1), p. 1-28, available at:

http://www.ilo.org/dyn/travail/docs/710/Labour\%20Code\%20of\%2023\%20September \%201946\%20as\%20amended.Publication\%202010.pdf [last accessed 28 September 2017].

As-Safir, “تحذيري في انتظار أخر شباط إضراب أستاذ إلى لحوار المقطوع يدفع •r ألف, As-Safir, 13 February 1996.

As-Safir, “في Yv الحالي جمعية عمومية و لقاءات مناطقية لتنفيذ الإضراب," As-Safir, 7 February 1996.

As-Safir, “مجلس الوزراء يؤكد قرار منع التظاهر و يكلف الجيش ضبط الأمن لمدة r أشهر Asafir, 28 February 1996.

As-Safir, “مكتب الاتحاد العام يزور مروة اليوم," As-Safir, 29 January 1983.

As-Safir, “مو اقف نيابية تتنق مقرر ات مجلس الوزراء الاخيرة," As-Safir, 27 October 1995.

20

This paper was first published in the 3rd issue of the Civil Society Review:

https://civilsocietycentre.org/resource/civil-society-review-issue-3-unraveling-\%E2\%80\%9Ccivil-

society\%E2\%80\%9D-policydependency-networks-and

Published on Lebanon Support's Civil Society Knowledge Centre: https://civilsocietycentre.org/paper/understanding-state-incorporation-workers-movement-early-post-war-lebanonand-its-backlash 
As-Safir,“غير صحية التي تر افق التحضير للانتخابات نتيجة الأجواء, As-Safir, 21 January 1983.

As-Safir, “القيادة العمالية: عدَة المعركة تكتمل,” As-Safir, 17 April 1997.

Ismail Badran, Mohamad Zbib, “الاتحاد العمالي العام في لبنان," Beirut, Friedrich Ebert Stiftung, 2004.

Sami Baroudi, "Economic Conflict in Postwar Lebanon: State - Labor Relations between 1992 and 1997," Middle East Journal, Washington DC, The Middle East Institute, 1998, Vol. 52 (4).

Hannes Baumann, Citizen Hariri and Neoliberal Politics in Postwar Lebanon, London, SOAS University of London, 2012.

Hannes Baumann, "Social Protest and the Political Economy of Sectarianism in Lebanon," Global Discourse, Abingdon, Taylor and Francis, 2016, Vol. 6 (4).

Rula Baydoun, “الحركة العمالية: من النضال للوحدة الى ضياع وحدة النضال, An-Nahar, 15 May 1997.

Eva Bellin, "Coercive Institutions and Coercive Leaders,” (ed.) Marsha Posusney and Michele Angrist (eds.), Authoritarianism in the Middle East: Regimes and Resistance, Colorado, Lynne Rienner Publishers, 2005.

Ruth Berins Collier and David Collier, Shaping the Political Arena: Critical Junctures, the Labor Movement, and Regime Dynamics in Latin America, Princeton, Princeton University Press, 1991.

Toufic Gaspard, A Political Economy of Lebanon, 1948-2002, Leiden, Brill, 2004.

General Confederation of Workers in Lebanon, “ق "نقرير مؤتمر النقابي الوطني العام, GCWL, 13 December 1994.

Peter Hall and Rosemary Taylor, "Political Science and the Three New Institutionalisms," MPIFG Discussion Paper, Koeln, Max-Planck-Institut für Gesellschaftsforschung, 1996.

Issam al-Jurdi, “هل تفتح استقالة الزغبي معركة الهيكلية لاعادة التوحيب؟, An-Nahar, 13 May 1998.

Diana Kallas, "al-Qada' Yu' addi Dawr fi Himayat al-Hurriyyat al-Naqabiyya Raghma alThugurat al-Kanuniyya: Fahal Yastajib al-Musharri'?”, The Legal Agenda, 12 November 2012, available at: http://legal-agenda.com/makalat.php?katib=75 [last accessed 19 April 2018].

21

This paper was first published in the 3rd issue of the Civil Society Review: https://civilsocietycentre.org/resource/civil-society-review-issue-3-unraveling-\%E2\%80\%9Ccivilsociety\%E2\%80\%9D-policydependency-networks-and Published on Lebanon Support's Civil Society Knowledge Centre: https://civilsocietycentre.org/paper/understanding-state-incorporation-workers-movement-early-post-war-lebanonand-its-backlash 
Imad Marmal, “تقرير ان حول وقائع و اصداء لقاء الحريري- ابو رزقت,” As-Safir, 13 March 1996.

Michael Morley, Patrick Gunnigle, and David Collings, Global Industrial Relations, London, Routledge, 2006.

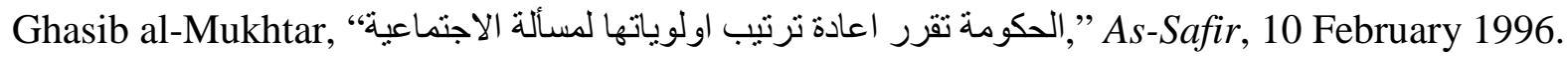
Nabil Nasser, “لنكن واحدا في استقبالهة" An-Nahar, 26 April 1997.

Marco Retting, "The Role of the Banking Sector in the Economic Process of Lebanon, before and after the Civil War.”, Master Thesis, London, School of Oriental and African Studies, University of London, 2010.

Gay Seidman, Manufacturing Militance: Workers' Movements in Brazil and South Africa, 1970-1985, Berkeley, University of California Press, 1994.

Rita Sharara, “بري : حري توجيه الاعتصام ضد الحكومة لا ضد زيارة شير الك," An-Nahar, 4 April 1996.

This paper was first published in the 3rd issue of the Civil Society Review: https://civilsocietycentre.org/resource/civil-society-review-issue-3-unraveling-\%E2\%80\%9Ccivilsociety\%E2\%80\%9D-policydependency-networks-and Published on Lebanon Support's Civil Society Knowledge Centre: https://civilsocietycentre.org/paper/understanding-state-incorporation-workers-movement-early-post-war-lebanonand-its-backlash 